\title{
СТАТИСТИЧНИЙ АНАЛІЗ ЛАЗЕРНИХ ПОЛЯРИЗАЦІЙНИХ ЗОБРАЖЕНЬ ПЛАЗМИ КРОВІ В ДІАГНОСТИЦІ ПАТОЛОГІЇ МОЛОЧНИХ ЗАЛОЗ
}

\author{
Н. І. Заболотна', Б. П. Олійниченко \\ Вінницький національний технічний університет ${ }^{1}$ \\ НВП ТОВ «Медівін»², м. Вінниця
}

\begin{abstract}
Виявлено тенденційні зміни статистичних моментів двовимірних розподілів азимутів і еліптичносте- поляризації лазерного зображення плазми крові людини. Оцінювання здійснено за умов припущення, що малий та підвищений рівень значення показника двопроменезаломлення відповідають станам плазми крові здорової людини та 3 патологією молочних залоз.
\end{abstract}

Ключові слова: поляризаційне зображення плазми крові, показник двопроменезаломлення, патологія молочних залоз, статистичні моменти, азимут поляризації, еліптичність поляризації.

\section{СТАТИСТИЧЕСКИЙ АНАЛИЗ ЛАЗЕРНЫХ ПОЛЯРИЗАЦИОННЫХ ИЗОБРАЖЕНИЙ ПЛАЗМЫ КРОВИ В ДИАГНОСТИКЕ ПАТОЛОГИИ МОЛОЧНЫХ ЖЕЛЕЗ}

\author{
Н. І. Заболотная ${ }^{1}$, Б. П. Олийниченко ${ }^{2}$ \\ Винницкий национальний технический университет ${ }^{1}$ \\ НПП ООО «Медивин» ${ }^{2}$, г. Винница
}

\begin{abstract}
Выявлены тенденционные изменения статистических моментов двумерных распределений азимутов и элиптичностей поляризации лазерного изображения плазмы крови человека. Оценивание осуществляется в условиях предположения, что малый и высокий уровень значения показателя двулучепреломления соответствуют состояниям плазмы крови здорового человека и с патологией молочних желез.
\end{abstract}

Ключевые слова: поляризационное изображение плазмы крови, показатель двулучепреломления, патология молочних желез, статистические моменты, азимут поляризации, елиптичность поляризации.

\section{STATISTICAL ANALYSIS OF LASER POLARIZATION IMAGES OF BLOOD PLASMA IN DETECTING OF MAMMARY GLANDS PATHOLOGY}

\author{
N. I. Zabolotna', B. P. Oliinychenko² \\ Vinnytsia National Technical University ${ }^{1}$ \\ SPC "Medivin", Vinnytsia
}

\begin{abstract}
There were found out changes of tendentious statistical moments of two-dimensional distribution of azimuth and ellipticity of polarization of a laser image of human blood plasma. Evaluation was carried out under the assumption that small and high level of birefringence reflects the state plasma "healthy person" and "pathology of mammary glands».
\end{abstract}

Key words: polarization images of blood plasma, the birefringence index, pathology of mammary glands, statistical moments, the polarization azi muth, polarization eliptychnist.

Вступ. Провідне місце на різних етапах діагностичного процесу в мамології посідає диференціювання та уточнення діагнозу. Для цього широко застосовують дослідження крові та визначення їі показників і параметрів, оскільки у біологічних рідинах відображаються специфічні зміни, характерні для певного типу патологічного процесу. 3 іншого боку, біологічні

(C) Н. І. Заболотна, Б. П. Олійниченко, 2011 рідини значно доступніші, менш травматичні для безпосереднього лабораторного аналізу, порівняно $з$ методами біопсії біологічних тканин $[1,2]$.

На даний час найбільш поширеними і апробованими в клінічній практиці є спектрофотометричні методи дослідження плазми крові, що засновані на аналізі змін інтенсивності поля розсіяного випромі- 
нювання оптично-неоднорідними біологічними рідинами [3].

Новим методом досліджень, що дозволяє отримати додаткову інформацію про зміну іншого типу оптичних параметрів біологічної рідини, є лазерна поляриметрія, яка базується на аналізі поляризаційних властивостей біологічних об'єктів при їх опроміненні лазерним поляризованим пучком.

Відомий цикл робіт [4-7], присвячений дослідженням процесів перетворення параметрів поляризації лазерного випромінювання мазками плазми крові. Вони грунтуються на представленні оптичних властивостей плазми крові, як двокомпонентної аморфно-кристалічної структури, кристалічна складова якої сформована сукупністю протеїнів, що володіють властивостями оптично одноосних двопроменезаломлюючих кристалів. На цій основі встановлено взаємозв'язки між набором статистичних моментів 1 - 4 порядків, що характеризують двопроменезаломлювальну архітектоніку плазми крові (розподіли напрямів оптичних осей (p) та фазових зсувів (5) сіток протеїнових фібрил), та сукупністю відповідних статистичних моментів двовимірних розподілів азимутів (а) та еліптичностей (Р) їх поляризаційних лазерних зображень при гострих хірургічних станах, зокрема при деструктивних формах гострого панкреатиту [8].

Проте, до цього часу не проводились дослідження можливостей застосування даних методик для діагностики патологічних змін у молочних залозах.

Мета роботи полягає в оцінюванні тенденцій змінен ня статистичних моментів двовимірних розподілів поляризаційних характеристик (азимутів та еліптичностей) лазерного зображення плазми крові за наявності та відсутності патології молочних залоз за допомогою однопараметричного комп'ютерного моделювання.

Основна частина. Основними аналітичними співвідношеннями для визначення поляризаційних характеристик зображень плазми крові є: азимути (a) та еліптичності (B). Ддя описання механізму взаємодії лазерного випромінювання з полікристалічними мережами білків плазми крові застосовується матричний оператор Мюллера, що найбільш повно характеризує поляризаційні властивості плазми крові як оптичного одновісного двопроменезаломлюючого кристала [9-14].

$$
\{Z\}_{j}=\left\|\begin{array}{cccc}
1 & 0 & 0 & 0 \\
0 & z_{22} & z_{23} & z_{24} \\
0 & z_{32} & z_{33} & z_{34} \\
0 & z_{42} & z_{43} & z_{44}
\end{array}\right\|
$$

$$
z_{i k}(\rho, \delta)=\left\{\begin{array}{l}
z_{22}=\cos ^{2} 2 \rho+\sin ^{2} 2 \rho \cos \delta ; \\
z_{23 ; 32}=\cos 2 \rho \sin 2 \rho(1-\cos \delta) \\
z_{33}=\sin ^{2} 2 \rho+\cos ^{2} 2 \rho \cos \delta \\
z_{34 ; 43}= \pm \cos 2 \rho \sin \delta \\
z_{24 ; 42}= \pm \sin 2 \rho \sin \delta \\
z_{44}=\cos \delta .
\end{array}\right.
$$

Тут $\rho$ - напрямок оптичної осі кристала; $\delta=2 \pi / \lambda \Delta n d$ - фазовий зсув, який вноситься між ортогональними складовими амплітуди лазерної хвилі довжиною $\lambda$, що проходить крізь білок з розміром $d$ та показником двопроменезаломлення $\Delta n$.

Класичне визначення матриці Мюллера $\{Z\}$ полягає в тому, що такий математичний оператор вичерпно повно характеризує процеси трансформації вектора Стокса оптико-анізотропними біологічними шарами [9-14]

$S^{*}=\{Z\} S_{0}$.

Тут $S_{0}, S^{*}$ - вектора Стокса опромінюючого і об'єктного пучків.

3 урахуванням (3) можна записати вектор Стокса $S^{*}$ у розгорнутому вигляді

$S^{*}=\left(\begin{array}{l}1 \\ S_{2} \\ S_{3} \\ S_{4}\end{array}\right)=\left(\begin{array}{l}1 \\ z_{22} S_{2}^{0}+z_{23} S_{3}^{0}+z_{24} S_{4}^{0} \\ z_{32} S_{2}^{0}+z_{33} S_{3}^{0}+z_{34} S_{4}^{0} \\ z_{42} S_{2}^{0}+z_{43} S_{3}^{0}+z_{44} S_{4}^{0}\end{array}\right)=\left(\begin{array}{l}1 \\ \cos 2 \alpha \cos 2 \beta \\ \sin 2 \alpha \cos 2 \beta \\ \sin 2 \beta\end{array}\right)$.

На основі (4) одержимо вирази для визначення азимута а і еліптичності р поляризації об'єктної електромагнітної хвилі

$$
\begin{aligned}
& \alpha=0,5 \operatorname{arctg}\left(\frac{S_{3}}{S_{2}}\right) \equiv u\left[z_{i k}(\rho, \delta)\right] \\
& \beta=0,5 \arcsin \left(S_{4}\right) \equiv p\left[z_{i k}(\rho, \delta)\right] .
\end{aligned}
$$

3 аналізу співвідношень (5) і (6) випливає, що стан поляризації $(\alpha, \beta)$ перетвореного лазерного випромінювання визначається відповідними локальними орієнтаційно - фазовими $(\rho, \delta)$ параметрами полікристалічної сітки протеїнів біологічної рідини.

В основу комп'ютерного моделювання процесів формування поляризаційно-неоднорідних зображень плазми крові покладено такі положення. 
• Кристалічна сітка представлена у вигляді впорядкованих за напрямами оптичних осей двопромнезаломлюючих циліндрів (кількість $\mathrm{N}=100$, діаметр $\otimes=50 \mu m$, показник двопроменезаломлення $\left.\Delta n=1,5 \times 10^{-3}\right)$ (рис. 1$)$.

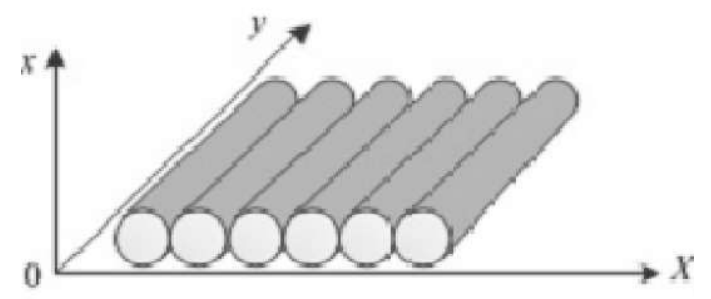

Puc. 1. Просторово впорядкована сітка циліндричних кристалів.

- Процес формування поляризаційно неоднорідних зображень полікристалічної мережі за умов багаторазового розсіяння моделюється за допомогою подвійного дифракційного інтеграла Релея - Зомерфельда [10].

- Розглядаються два типи полікристалічних мереж 3 різним показником двопроменезаломлення $\Delta n=1,5 \times 10^{-3}-$ група $1 ; \Delta n^{*}=1,5 \times 10^{-2}-$ група 2 ;

Припускаємо, що малий рівень $\left(\Delta n=1,5 \times 10^{-3}\right)$ двопроменезаломлення відповідає моделі мережі кристалів плазми крові здорової людини, підвищений рівень $\left(\Delta n^{*}=1,5 \times 10^{-2}\right)$ відповідає стану з патологічними змінами у молочних залозах;
Найбільш об'єктивно координатні розподіли поляризаційних параметрів зображень полікристалічних мереж обох груп характеризує сукупність статистичних моментів $Z_{k=1 ; 2 ; 3 ; 4}$, обчислена за співвідношеннями [9,14]

$$
\begin{gathered}
Z_{1}=\frac{1}{N} \sum_{i=1}^{N}\left|(q)_{i}\right| ; \\
Z_{2}=\sqrt{\frac{1}{N} \sum_{i=1}^{N}(q)_{i}^{2}} \\
Z_{3}=\frac{1}{Z_{2}^{3}} \frac{1}{N} \sum_{i=1}^{N}(q)_{i}^{3} ; \\
Z_{4}=\frac{1}{Z_{2}^{2}} \frac{1}{N} \sum_{i=1}^{N}(q)_{i}^{4},
\end{gathered}
$$

де N - повна кількість значень поляризаційного параметра q .

На основі наведених аналітичних положень засобами пакета прикладних програм МЛТЬЛБ 6 було проведено формування поляризаційних мап двох типів полікристалічних мереж з різними показниками двопроменезаломлення, результати якого наведені на рисунках 2,3 .

Результати та обговорення. Аналіз поляризаційних мап $a(m \times n)$ і $\quad b(m \times n)$ зображення полікристалічної мережі групи 1 (рис. 2) виявив складну координатно-неоднорідну структуру. Для гістограм

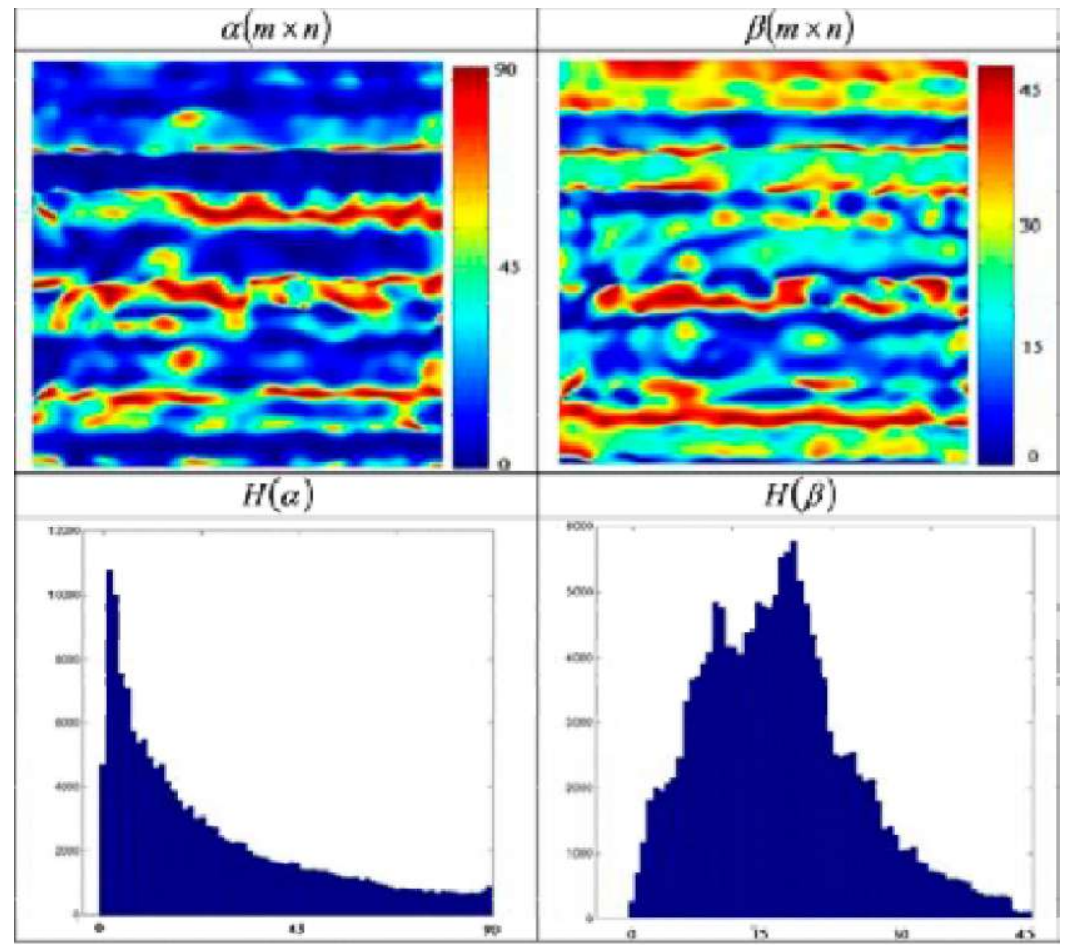

Puc. 2. Поляризаційні мапи $a(m \times \mathrm{n})$, $b(m \times n)$ і гістограми розподілів значень азимутів $H(\alpha)$ і еліптичності $H(\beta)$ поляризації зображення модельної двопроменезаломлюючої сітки групи 1. 
розподілу випадкових значень $H(\alpha)$ і $H(\beta)$ характерний максимально широкий діапазон зміни $\left(0^{0} \leq \Delta \alpha \leq 90^{\circ}\right.$ i $\left.0^{\circ} \leq \Delta \beta \leq 45^{\circ}\right)$ значень азимуту $\mathrm{i}$ еліптичності поляризації лазерного випромінювання, перетвореного просторово-орієнтованими парціальними кристалами 3 малим двопроменеазаломленням $\Delta n=1,5 \times 10^{-3} .3$ іншого боку, залежності гістограм
$H(a)$ i $H(\mathrm{~b})$ асиметричні та суттєво відрізняються між собою.

Кількісно оптичні прояви анізотропії впорядкованої мережі парціальних двопроменезаломлюючих кристалів групи 1 ілюструє сукупність значень статистичних моментів 1-го - 4-го порядків (табл. 1), обчислена за співвідношеннями (7).

Таблиця 1. Статистичні моменти 1-го - 4-го порядків =1·2.3.4 координатних розподілів азимутів a $\mathrm{i}$ еліптичності р поляризації зображення модельної двопроменезаломлюючої сітки груп 1 та 2

\begin{tabular}{|c|c|c|c|c|}
\hline \multirow{2}{*}{$Z_{k=1 ; 2 ; 3 ; 4}$} & \multicolumn{2}{|c|}{$\alpha(m \times n)$} & \multicolumn{2}{c|}{$\beta(m \times n)$} \\
\cline { 2 - 5 } & Група 1 & Група 2 & Група 1 & Група 2 \\
\hline$Z_{1}$ & 0,05 & 0,05 & 0,14 & 0,14 \\
\hline$Z_{2}$ & 0,26 & 0,29 & 0,32 & 0,36 \\
\hline$Z_{3}$ & 1,85 & 1,18 & 2,16 & 1,61 \\
\hline$Z_{4}$ & 1,51 & 0,87 & 1,37 & 0,98 \\
\hline
\end{tabular}

3 аналізу наведених у таблиці 1 даних випливає, що для ймовірнісних розподілів випадкових значень азимуту а і еліптичності р поляризації лазерного зображення двопроменезаломлюючої сітки групи 1 характерною є перевага величин статистичних моментів вищих (3-го і 4-го) порядків- $Z_{i=3 ; 4}^{\alpha ; \beta} \succ \succ Z_{i=1 ; 2}^{\alpha ; \beta}$.

Одержана інформація про координатний $(m \times n)$ (рис. 3) і імовірнісний (статистичний) $H(\alpha) ; H(\beta)$ розподіл значень азимутів і еліптичності поляризації модельного лазерного зображення свідчить про зростання впливу оптичного двопроменезаломлення полікристалічної мережі групи 2.

Аналіз гістограм $H(\alpha) ; H(\beta)$ поляризаційних мап виявив зростання ймовірностей значень азимутів $\mathrm{i}$ еліптичності поляризації у всьому діапазоні зміни їх величин $0^{\circ} \leq \Delta \alpha \leq 90^{\circ}$ i $0^{\circ} \leq \Delta \beta \leq 45^{\circ}$ (рис. 3) у порівнянні із аналогічним розподілом параметрів по-

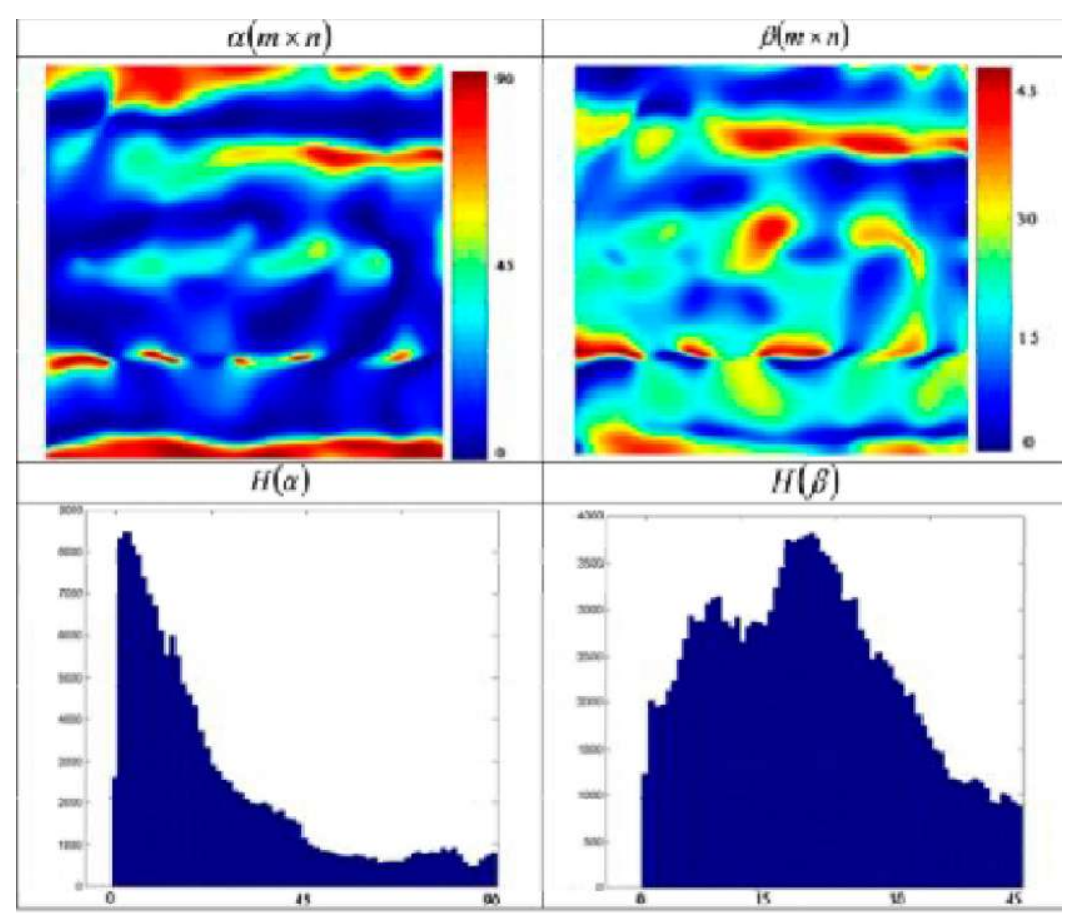

Puc. 3. Поляризаційні мапи $a(m \times n)$,

$$
\beta(m \times n), \beta(m \times n) \text { і гістограми }
$$

розподілів значень азимутів $H(\alpha)$ і еліптичності поляризації $H(\beta)$ зображення модельної двопроменезаломлюючої сітки групи 2. 
ляризації модельного лазерного зображення полікристалічної мережі групи 1 (рис. 2).

Кількісно зміни величини двопроменезаломлення

$\left(\Delta n^{*}=1,5 \times 10^{-2}\right)$ полікристалічної мережі групи 2 ілюструє певне зростання (на $30 \%$ ) статистичного моменту 2-го порядку та зменшення (в 1,5 - 2 рази) статистичних моментів 3-го і 4-го порядків, що характеризують координатну структуру поляризаційних мап $\alpha(m \times n)$ і $\beta(m \times n)$.

Висновки. В результаті проведеного моделювання формування поляризаційних мап двох типів полікри-

\section{Література}

1. Тарутинов В. И. Молочная железа: рак и предраковые заболевания / В. И. Трутинов. - К. : Полиграфист, 2006. $415 \mathrm{c}$.

2. Зотов А. С. Мастопатии и рак молочной железы / А. С. Белик, Е. О. Зотов. - М. : Медпресс-информ, 2005. - 111с.

3. Баркаган 3. С. Диагностика и контролируемая терапия нарушений гемостаза / З. С. Баркаган, А. П. Момот. - М. : Ньюдиамед-АО, 2001. - С. 296.

4. Polarization phase reconstruction of biological tissue architectonics: Part 2. Study of polarizing intercorrelative function of coherent images of phase-inhomogeneous layer anisotropy/ A. O. Angelskaya, A. G. Ushenko, Yu. A. Ushenko [et al.] // Proc. SPIE. - 2007. - Vol. 6635. - P. 66350LP.

5. Polarization phase reconstruction of biological tissue architectonics: Part 3. Polarizing-correlative processing of images of statistical objects in the problem of visualization and topology reconstruction of their phase heterogeneity / A. O. Angelskaya, A. G. Ushenko, Yu. A. Ushenko, A. Dubolazov [et al.] // Proc. SPIE. - 2007. - Vol. 6635. - P.66350MP.

6. Dubolazov A. Polarization phase reconstruction ofbiological tissue architectonics: Part 4. Coherent introscopy of phaseinhomogeneous surface and layers / A. O. Angelskaya, A. G. Ushenko, Yu. A. Ushenko [et al.] // Proc. SPIE. - 2007. - Vol. 6635. - P. 66350NP.

7. Alexander Dubolazov. The Degree of Mutual Correlation of Coordinate Distributions of Muller Matrix Elements Biological Tissues and Diagnostics of Their Physilogacal State/ Y. A. Ushenko, Yurij Ya. Tomka, Alexander Dubolazov // Proc.Vol.2 ST-OPTO 2009, 347-352, (2009). сталічних мереж з різними показниками двопроменезаломлення та статистичного аналізу отриманих зображень азимуту і еліптичності поляризації виявлена чутливість статистичних моментів 3-го, 4-го порядків до змін (зростання) двопроменезаломлення парціальних циліндричних кристалів білків плазми крові.

Отже, отримані тенденційні результати слугують теоретичним підгрунтям для подальшого застосування методів лазерної поляриметрії полікристалічних мереж білків плазми крові в експериментальних дослідженнях 3 виявлення патологічних змін у молочних залозах.

8. Івашук О. І. Зміна оптичних параметрів лазерної поляриметрії плазми крові за гострого деструктивного панкреатиту / О. І. Івашук, О. Г. Ушенко, І. К. Морар, В. Ю. Бодяка // Буковинський медичний вісник. - 2010. - Т.14, N³ - С. 19-26. 9. Ushenko A. G. Laser Polarimetry of Biological Tissue: Principles and Applications / A. G. Ushenko, V. P. Pishak // Handbook of Coherent-Domain Optical Methods: Biomedical Diagnostics, Environmental and Material Science.- 2004. - Vol. 1, - P. 93-138.

10. Ushenko A. G. Polarization structure of laser scattering fields / A. G. Ushenko // Optical Engineering. - 1995. Vol. 34(4). - p. 1088-1093.

11. Ushenko A. G. Polarization-Phase Mapping and Reconstruction of Biological Tissue Architectonics during Diagnosis of Pathological Lesions / A. G. Ushenko, D. N. Burkovets, Yu. A. Ushenko// Optics and Spectroscopy. - 2002. - Vol. 93(3). - P. 449-456.

12. Fercher A. F. Optical coherence tomography - principles and applications / A. F. Fercher// Rep. Prog. Phys. - 2003. № 66. - P. 239-303.

13. Johannes de Boer. F. Review of polarization sensitive optical coherence tomography and Stokes vector determination / Johannes F. de Boer, Thomas E. Milner// J. Biomed. Opt. 2002. - Vol. 7. - P. 359-371.

Evolution of Statistic Moments of 2D-Distributions of Biological Liquid Crystal Net Mueller Matrix Elements in the Process of Their Birefringent Structure Changes / A. G. Ushenko, I. Z. Misevich, V Istratiy [et al.] // Advances in Optical Technologies. - 2010. - Article ID 423145. 